\title{
Design of Jigessa Small Scale Irrigation in Dara Woreda, Southern Ethiopia
}

\author{
Hailemariam Doko', Ermias Birhane1, Mihret Ulsido² \\ ${ }^{1}$ Indian Institute of Technology Roorkee, Roorkee, India \\ ${ }^{2}$ Wuhan University of Technology, Wuhan, China \\ Email: hailemariam01@gmail.com, ermasiasy@gmail.com, mihret@gmail.com
}

Received 9 April 2016; accepted 24 April 2016; published 28 April 2016

Copyright (C) 2016 by authors and OALib.

This work is licensed under the Creative Commons Attribution International License (CC BY). http://creativecommons.org/licenses/by/4.0/

(c) (i) Open Access

\begin{abstract}
The artificial application of water to land to aid crop production has enabled man to increase his ability to produce food and cash crops. All-the-year round crop production is now possible instead of the previous restriction to rain fed agriculture. However, conserving water and delivery it to the fields in an efficient manner has continued to be a challenge. The design of small-scale irrigation project will provide supplementary irrigation for many farmers. This paper presents design of small scale irrigation in Dara Wereda by assessing irrigation agronomy, analyzing hydrological condition of the area and designing different engineering structures like the headwork structure, main canal, cross drainage structure, etc. and also analyzing the stability of the structure which already designed. The structure we design in this project will resist the 50 year return period peak flood. Design considerations of canals naturally vary according to the type of soil. Again, the velocity of flow in the canal should critical. The canals cross the natural drain or gullies so suitable structure must be selected and designed. Finally, we put our conclusion and the necessary recommendation for the government, society, university and stakeholders.
\end{abstract}

\section{Keywords}

Small Scale Irrigation, Peak Flood, Agronomy

Subject Areas: Environmental Sciences, Hydrology

\section{Introduction}

Water is the greatest resource of humanity. It not only helps in survival but also helps in making life comfortable and luxurious, beside various other uses of water, the largest use of water in the world for irrigation lands [1].

Based upon the various river basin master plans and land and water resources surveys, the aggregate irrigation potentials of Ethiopia have been estimated to be 2,523,000 million hectares net and about 3.7 million hectare gross [2]. 
A large number of stream flows is available for utilization in irrigation, or any other use. With increasing demand for food production and maintaining agricultural sustainability, it is necessary to develop an integrated approach on land and water resource utilization. The availability of good agricultural land with a nearby flowing stream can enhance the utilization of the stream water by diverting the flow in to the canal system [3].

Jigessa small scale irrigation project is found in SNNP Regional Government Sidama Zone Dara special woreda. The project site is located at $2 \mathrm{KM}$ away from Tefrikella having a total distance of $10 \mathrm{~km}$ up to the head work site. The project is intended to irrigate about 100 ha land.

\section{Statement of the Problem}

On this project area there are some problems which are not tackled by the local farmers. Some visible problems observed in this woreda are:

$\Rightarrow$ Food insecurity in the area.

$\Rightarrow$ Backward tradition of agricultural practices, for the reason that they are dependent on yearly rainfall.

$\Rightarrow$ They cannot afford modern irrigation system because of their economic problems.

$\Rightarrow$ Rainfall in the study area is erratic, uneven and insufficient in its distribution and amount.

Why this problem exists their?

In adequate traditional and modern small scale irrigation schemes, this is due to

$\Rightarrow$ Insufficient attention of irrigation institutions to the area.

$\Rightarrow$ Lack of enough knowledge about importance and operation of modern irrigation.

$\Rightarrow$ Economical problem of the farmer.

\section{Literature Review}

Irrigation is practically a science of planning and designing a water supply system for the agricultural land to protect the crops from bad effect of draught or low rainfall [4].

A diversion head work (weir) is a structure constructed across a river for a purpose of raising water level in river so that it can be diverted in to off taking canals. Diversion head works are generally constructed on perennial rivers which have adequate flow throughout the year and therefore, there is no necessity of creating a storage reservoir [5].

According to MoWR, the following criteria are used for classification of irrigation projects in Ethiopia: Small Scale under 200 ha, Medium Scale 200 to 3000 ha and Large Scale over 3000 ha [6].

Diversion structure is a collection term for all (weir or diversion dam, head regulators, upstream and downstream river training work) at intakes of main or principal canal to divert and control river flow and to regulate water supplies in to the main canal or canal. A well-designed distribution system consisting of network of canal is required for caring water from the canal head works to the field [7].

Across drainage work is a structure which is constructed at the crossing a canal and a natural drain, so as dispose drainage water without interrupting continues canal supplies. It includes aqueduct, siphon aqueduct, super passage, level crossing, etc. [8].

\section{Objectives}

\subsection{General Objective}

To ensure food security of the society in Dara Woreda by supporting the rain fed agriculture with small-scale irrigation.

\subsection{Specific Objective}

$\checkmark$ To introduce modern irrigation system.

$\checkmark$ To analyze the agronomic and hydrology condition of the area.

$\checkmark$ To design the diversion head work structure and canal.

\section{Description of the Study Area}

Dara Woreda is located $120 \mathrm{Km}$ from Hawassa, Ethiopia. Jigessa small scale irrigation project is found in SNNP 
regional government sidama zone Dara special Woreda, Particularly the command area is located in woinadega agro ecological zone with mean elevation $1860 \mathrm{~m}$ above sea level. Farmers undertake mixed farming system.

According to the 1:50,000 topo-map interpretations, the estimated area of watershed is $72 \mathrm{~km}^{2}$. The catchment condition characterized by mountainous ride steep gorge land scape and the river is meandering and tributary to Lake Abaya.

\section{Material}

Most of the task to be carried out in this project is the design part or the office work which is to be done using different software and by referring different irrigation engineering books.

\section{Methodologies}

The design and analysis of Jigessa small scale irrigation project shall be carried out using formula, principles and theories which have been commonly used in irrigation system design.

\subsection{Irrigation Agronomy}

The crop types those are irrigated by the project area are Maize, Sorghum, coffee, mango, Onion, Sweet potato and Tomato. The crop coefficient (Kc) value of the above crop type is given by standard table. From this table we are going to take the Kc value at middle stage which needs much amount of water.

Determination of ETo: $\mathrm{ET}_{\mathrm{o}}$ can be determined using different empirical method in accordance with the available data.

Reference Crop Evapotranspiration (ETo): We use Blaney-criddle formula to determine ETo. Because it is suitable for calculating our data we got from the meteorology station.

$$
\mathrm{ETo}=P\left(T_{\text {mean }}+8.13\right)
$$

where, ETo = reference crop evapotranspiration (mm/day).

$P=$ mean daily percentage of annual day time hours.

To determine $P$, it is essential to know latitude of the area and read from the table. Teferikela is situated on latitude of $6.30 \mathrm{~N}$. But in the table there is no exact value for $6.30 \mathrm{~N}$. Therefore, to estimate the value of $P$ for 6.30 $\mathrm{N}$, we interpolate $\mathrm{b} / \mathrm{n} 5$ and 10 .

Dependable Rainfall: We calculated the probability of the rainfall using the following formula.

$$
P=\frac{R}{N+1}
$$

where, $P=$ Probability (\%), $R=$ Rank and $N=$ Number of years.

The rainfall for our irrigation design should have a probability of $80 \%$. But since there is no exact value of $80 \%$, we get the value by interpolation.

Effective Rainfall: Effective rainfall can be computed using the following formula.

$$
\text { Peff }=\left\{\begin{array}{l}
0.6 \text { Pdep }-10, \text { if Pdep }<70 \mathrm{~mm} / \text { month } \\
0.8 \text { Pdep }-24, \text { if Pdep }>70 \mathrm{~mm} / \text { month }
\end{array}\right.
$$

Crop Coefficient (Kc): Different crops have different Kc values at different stage. Among these crops we took the largest Kc value. I.e. Kc $=1.2$. Thus not to make other crops stressed.

Actual Crop Evapotranspiration (ETc): ETc can be calculated by the formula:

$$
\mathrm{ETc}=\mathrm{ET} \mathrm{o} \times \mathrm{Kc}
$$

\section{NET Irrigation Requirement (NIR)}

$$
\mathrm{NIR}=\mathrm{ETc}-\text { Peff, GIR }=\frac{\text { NIR }}{\eta} \text { where } \eta=\text { project efficiency }=0.65
$$

Duty: We take the maximum value of GIR to compute the duty.

$$
\begin{aligned}
\text { Duty } & =\operatorname{GIR}(\mathrm{mm} / \text { day }) \times \operatorname{Area}(\text { ha }) / \text { period }(\text { hours } / \text { day }) \\
& =(8.369 \mathrm{~mm} / \text { day } \times 1 \text { ha }) /(10 \mathrm{hr} / \text { day })=2.3 \times 10^{-3} \mathrm{~m}^{3} /(\text { ha } \cdot \text { sec })
\end{aligned}
$$




\section{Design Discharge}

Now, we are going to irrigate a command area of 100ha of the Jigessa kebele by considering the downstream users of the river.

The demand discharge can be computed by the following formula.

$$
Q=A \times \text { Duty }=100 \mathrm{ha} \times 2.3 \mathrm{~m}^{3} /(\mathrm{sec} \cdot \mathrm{ha})=0.230 \mathrm{~m}^{3} / \mathrm{sec}=230 \mathrm{lit} / \mathrm{sec}
$$

The base flow of the river is 250 lit/sec, which means it can satisfy the project's water requirement at any time of the season.

\subsection{Hydrology Analyses}

Since "Jigessa" river is not gagged, it is not possible to determine the peak flood from the gauged varieties of hydrological phenomena.

\subsubsection{Estimation of Design Rain Fall}

The maximum flood is determined in order to design the diversion head work capable of withstanding any disaster caused by the peak flood which may come in 50 years return period.

\section{Statistical Analysis}

The raw data shown in Table 1 is required to estimate design rainfall is daily maximum point rainfall for 16 years because there is shortage of data in the area. But this data by itself can't tell the upcoming design rainfall for the required return periods (50 years).Therefore, in order to convert this data and make serve for design rainfall estimation it should pass through statistical analysis.

a) Normal series statistical analysis.

b) Log transferred series statistical analysis.

\section{Statistical model distribution for 25 and 50 years return period}

The statistical model distribution is important in order to determine the upcoming peak flood once over the period of 25 and 50 years which in turn matters the design of the diversion weir. Then the design daily point rain fall for 25 and 50 years return period is assumed to follow different types of statistical model distribution, therefore in order to estimate the design rain fall from the given 16 years data shown in Table 1 the computation goes through different statistical model distributions:

Normal distribution: Design rainfall, $X_{t}=\bar{X}+K t(25) \times S x$.

Log Normal distribution: Design rainfall, $\mathrm{Xt}=$ anti $\log [\overline{\mathrm{y}}+\mathrm{Kt} 25 \times \mathrm{Sy}]$.

Gumble (Extreme I) distribution: Design rainfall, $\mathrm{Yt}=-\ln \left(-\ln \left(1-\frac{1}{5}\right)\right)$.

Pearson type III distribution: Design rainfall, $\mathrm{Xt}=\overline{\mathrm{X}}+(\mathrm{Kt} \times \mathrm{Sx})$.

Log Pearson type III distribution: Design rainfall, $\mathrm{Xt}=\operatorname{anti} \log [\overline{\mathrm{y}}+\mathrm{Kt} \times \mathrm{Sy}]$.

In order to choose the design rainfall for 50 year we select the smallest difference on statistical model distribution shown in Table 2. Therefore, the design rainfall for this project is taken from normal distribution design of rainfall $\mathbf{7 3 . 9 0} \mathbf{~} \mathbf{m m}$ for $\mathbf{5 0}$ year.

\subsubsection{Peak Flow Estimation}

The maximum expected flood of the stream for a return period of 50 year of the river is computed by soil conservation service method (SCS) and Slope-Area method. Then the maximum of the two is taken for designing the structures. We took the largest which is equal to $104.88 \mathrm{~m}^{3} / \mathrm{sec}$ for designing our structures.

Table 1. Row data required to estimate design rainfall.

\begin{tabular}{cccccccccc}
\hline Year & 1984 & 1985 & 1986 & 1987 & 1988 & 1989 & 1990 & 691 \\
Daily Maximum R.F & 61 & 34 & 39.5 & 56.4 & 61 & 60.5 & 66.8 & 190.4 \\
Year & 1992 & 1993 & 1994 & 1995 & 1996 & 1997 & 1998 \\
Daily Maximum R.F & 49.2 & 50.6 & 59.3 & 42 & 44.2 & 36.2 & 65.2 \\
\hline
\end{tabular}


Table 2. Summary of 25 and 50 year flood.

\begin{tabular}{cccc}
\hline Statistical model distribution & For 25 years & For 50 years & Difference \\
\hline Normal distribution & $\mathbf{7 0 . 7 3}$ & $\mathbf{7 3 . 9}$ & $\mathbf{3 . 1 7}$ \\
Log normal distribution & 75.94 & 79.763 & 3.823 \\
Gumble (extreme I) distribution & 78.88 & 85.86 & 6.98 \\
Pearson type III distribution & 73.29 & 78.17 & 4.88 \\
Log Pearson type III distribution & 77.11 & 84.42 & 7.31 \\
\hline
\end{tabular}

\subsection{Engineering Design}

\subsubsection{Head Work}

For the weir site selection convenient cross-section of the river should full fill the following criterion: The weir site should be at the narrow ended and straight reach of the river. The elevation of the weir site should be located at a place where maximum command area can be irrigated. And the area should have to be located at a location where there is a good geological formation for foundation and the material of construction should available in vicinity of the site. After the convenient weir site is selected height of the weir is going to be determined:

\section{1) Design of Weir Body}

\section{Height of the Weir}

The Elevation of the river bed (weir axis elevation) and command area are $1858.5 \mathrm{~m}$ and $1856.5 \mathrm{~m}$ asl respectively

$$
\begin{gathered}
H^{\prime}=1858.5-1856.5=2 \mathrm{~m} \\
H=H^{\prime}+D+0.7
\end{gathered}
$$

where, $H$ = height of the weir.

$H^{\prime}$ = the height that brings the level of river to that of the command area.

Use orifice formula to determine the Diameter of the intake $D$.

$$
Q=C_{d} A \sqrt{2 g h}
$$

where $Q=$ design discharge $=230 \mathrm{lit} / \mathrm{sec}=0.23 \mathrm{~m}^{3} / \mathrm{sec}$.

$A=$ cross sectional area of the intake.

$h=$ driving head above the piping center.take 0.4.

$C_{d}=$ discharge coefficient $=0.6$.

This helps to determine the Diameter of the intake $D$

$$
\begin{gathered}
Q=C_{d} \frac{\pi D^{2}}{4} \sqrt{2 g h} \\
0.23 \mathrm{~m}^{3} / \mathrm{sec}=0.6 \times A \times \sqrt{2 \times 9.81 \times 0.4} \\
\frac{\pi D^{2}}{4}=\frac{0.23}{0.6 \times \sqrt{2 \times 9.81 \times 0.4}}=0.136 \\
D=\sqrt{\frac{0.136 \times 4}{\pi}}=0.42 \cdots=0.5 \mathrm{~m} \\
Q_{d}=C_{d} A_{d} \sqrt{2 g h} \\
\text { wier })=0.6 \times \frac{\pi \times 0.5^{2}}{4} \sqrt{2 \times 9.81 \times 0.4}=0.33 \mathrm{~m}^{3} / \mathrm{sec}
\end{gathered}
$$

But the design discharge is $0.33 \mathrm{~m}^{3} / \mathrm{sec}$;

$Q_{d}($ wier $)>Q_{\text {available }}$ safe!! 
$0.33>0.23$ ok!!

Therefore, total crest height of the weir will be;

$$
H=H^{\prime}+D+0.5 \mathrm{~m}+0.2=2 \mathrm{~m}+0.5 \mathrm{~m}+0.7 \mathrm{~m}=3.2 \mathrm{~m}
$$

\section{Cross Sectional Design}

A masonry broad crested weir is selected due to the simplicity of construction and availability of stone near the project area.

* Shape of the weir =broad crested.

- $Q_{\max }=104.88 \mathrm{~m}^{3} / \mathrm{sec}$ (Peak discharge).

- Length of the weir $=10 \mathrm{~m}$.

- Height of the weir; $H=3.2 \mathrm{~m}$.

- $\quad$ Crest level of the weir $=1858.5+3.2=1861.7 \mathrm{~m}$.

Total energy of the crest;

$$
H_{e}=H_{d}+\frac{V_{d}^{2}}{2 g}
$$

$H_{d}=$ Design water head over the crest (a function of peak flood $Q$ ).

$V_{a}=$ approaching velocity of the peak flood,

$$
v_{a}=\frac{Q_{P}}{L \times\left(H_{d} \times P\right)}
$$

Therefore, the following parameters can be found as follows;

$$
Q_{p}=C_{p} \times H_{d}^{3 / 2} \times L
$$

where: $C_{p}$-flow coefficient $=2.2$.

$$
\begin{gathered}
H_{d}=\left[\frac{Q_{p}}{C_{d} \times L}\right]^{\frac{2}{3}}=\left[\frac{104.88}{2.2 \times 10}\right]^{\frac{2}{3}}=2.83 \mathrm{~m}, V_{a}=\frac{104.88}{[10 \times(2.83+3.2)]}=1.74 \mathrm{~m} / \mathrm{sec} \\
H_{a}=\frac{V_{a}^{2}}{2 \times g}=\frac{1.74^{2}}{2 \times 9.81}=0.15 \mathrm{~m}, H_{e}=H_{d}+\frac{V_{a}^{2}}{2 \times g}=2.83+0.15=2.98 \mathrm{~m}
\end{gathered}
$$

\section{Top width and Bottom Width of the Weir Cross Section}

$$
\begin{gathered}
\text { Top width } B_{1}=\frac{H_{e}}{\sqrt{G-1}}=\frac{2.98}{\sqrt{2.24-1}}=2.67=2.7 \mathrm{~m} \\
\text { Bottom width } B_{2}=\frac{H_{e}+H}{\sqrt{G-1}}=\frac{2.98+3.2}{\sqrt{2.24-1}}=5.549=5.6 \mathrm{~m}
\end{gathered}
$$

Hydraulic jump is the jump of water that takes place when a super critical flow changes in to a sub critical flow as shown in Figure 1.

Hydraulic jump is the jump of water that takes place when a supper critical flow changes in to a subcritical flow. Total energy head calculation at $\mathrm{u} / \mathrm{s}$

$$
\begin{gathered}
\mathrm{U} / \mathrm{S} \text { HFL }=\mathrm{RBL}+H+H_{d}=1858.5+3.2+2.83=1864.53 \mathrm{~m} \\
\mathrm{U} / \mathrm{S} \mathrm{TEL}=\mathrm{U} / \mathrm{S} \mathrm{HFL}+H_{a}=1864.53+0.15=1864.68 \mathrm{~m}
\end{gathered}
$$

By continuity equation

$$
\begin{gathered}
V_{1}=Q /\left(y_{1} \times L\right)=104.88 /\left(y_{1} \times 10\right)=10.488 / y_{1} \\
H_{e}+H=y_{1}+V_{1}^{2} /(2 \times g) y_{1}+5.6 /\left(y_{1}^{2}\right)-6.18=0
\end{gathered}
$$

By trial and error the value of $y_{1}$ for this polynomial expression can be found as; $y_{1}=1.04 \mathrm{~m}$ the approximate solution with a minimum value or almost zero 
U/S TEL

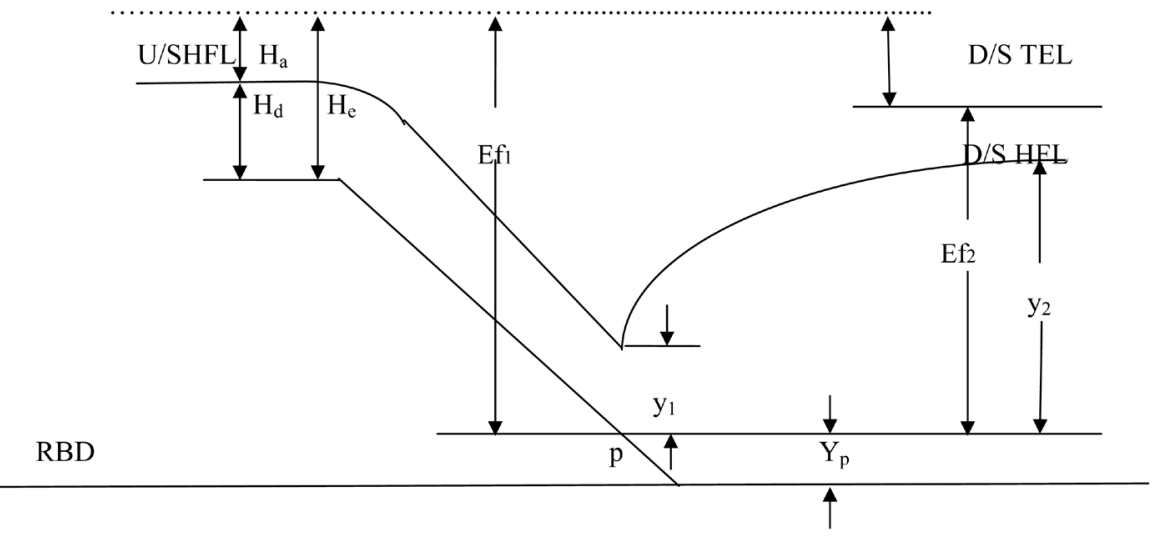

Figure 1. Hydraulic jump.

$$
\begin{gathered}
V_{1}=q / y_{1}=10.488 / 1.04=10.08 \mathrm{~m} / \mathrm{s} \\
y_{2}=y_{1} / 2\left[\sqrt{\left(1+8 \mathrm{Fr1}^{2}\right)}-1\right] \text { where, }\left(\text { Froude } № \text { ) Fr1 }=V_{1} / \sqrt{\left(g \times y_{1}\right)}=3.15\right. \\
y_{2}=1.04 / 2\left[\sqrt{\left(1+8 \times(3.15)^{2}\right)}-1\right]=4.14 \mathrm{~m} \\
V_{2}=q / y_{2}=Q /\left(y_{2} \times 10\right)=104.88 /(4.14 \times 10)=2.53 \mathrm{~m} / \mathrm{s}
\end{gathered}
$$

The head loss as a result of the jump $\left(H_{L}\right)$

$$
H_{L}=\left(y_{2}-y_{1}\right)^{3} /\left(4 \times y_{1} \times y_{2}\right)=(4-1.04)^{3} /(4 \times 1.04 \times 34.14)=1.7 \mathrm{~m}
$$

$\mathrm{D} / \mathrm{S}$ HFL before construction $=1863.60 \mathrm{~m}$

$$
\begin{gathered}
\mathrm{D} / \mathrm{S} \text { TEL }=\mathrm{d} / \mathrm{s} \mathrm{HFL}+V_{2} / 2 g=1863.60+0.15=1863.75 \mathrm{~m} \\
\mathrm{Ef} 2=y_{2}+v_{2}^{2} /(2 \times g)=4.14+2.53^{2} /(2 \times 9.81)=4.46 \\
\mathrm{Yp}=\mathrm{D} / \mathrm{S} \text { TEL }-\mathrm{Ef} 2=1863.08-4.46=1858.57 \mathrm{~m} \\
\mathrm{Ef} 1=\mathrm{Ef} 2+H_{L}=4.46+1.7=6.16
\end{gathered}
$$

\section{Stability Analysis of the Weir}

There are different forces that are used to compare the stability of the weir such as self-weight of the weir, water load, silt pressure and Uplift pressure. The stability analysis considers two situations the weir should with stand and faced with. These are maximum flood condition and normal pond level conditions. Therefore from stability of weir analysis check all forces acting on the weir of designed to with stand all force.

\section{Design of Weir Cut off}

\section{1) Depth of Upstream and Downstream Piles}

From lacey's factor

$$
f=1.76 \sqrt{d_{s}}
$$

where, $d_{s}=$ mean particle size and taken as 0.65

$$
f=1.76 \sqrt{0.65}=1.42
$$

Regime scour depth

$$
R=1.35\left(\frac{q^{2}}{f}\right)^{\frac{1}{3}} ; q=\frac{Q}{L}=\frac{104.88}{10}=10.488 \mathrm{~m}^{2} / \mathrm{sec}
$$




$$
\begin{gathered}
\qquad R=1.35\left(\frac{10.488^{2}}{1.42}\right)^{\frac{1}{3}}=5.75 \mathrm{~m} \\
\text { Regime velocity } v=\frac{q}{R}=\frac{10.488 \mathrm{~m}^{2} / \mathrm{sec}}{5.75 \mathrm{~m}}=1.82 \mathrm{~m} / \mathrm{sec}
\end{gathered}
$$

Depending on the above parameters, the upstream and downstream pile depths can be determined and as shown on Figure $2 d_{1}$ and $d_{2}$ are calculated as follows

$$
\begin{gathered}
d_{1}=\mathrm{u} / \mathrm{sHFL}-1.5 R=1864.53-1.5 \times 5.75=1855.9 \mathrm{~m} \text { asl, } d_{1}=1858.5-1855.9=2.59 \mathrm{~m} \\
d_{2}=\mathrm{d} / \mathrm{sHFL}-2 R=1863.60-2 \times 5.75=1852.1 \mathrm{~m} \text { asl, } d_{2}=1858.5-1852.1=6.4 \mathrm{~m}
\end{gathered}
$$

\section{2) Design of Impervious Apron}

As shown in Figure 2, the Purpose of apron in the weir structure is to resist uplift pressures and to dissipate the incoming energy over the weir.

a) Downstream impervious apron,

$$
L_{1}=2.21 C \sqrt{\frac{H}{10}}, \quad C=15, \quad L_{1}=2.21 \times 15 \times \sqrt{\frac{3.2}{10}}=18.75 \mathrm{~m} .
$$

b) Upstream impervious apron

$$
\begin{aligned}
& L_{1}=L_{T}-L_{1}-2 d_{1}-2 d_{2}-B, L_{T}=C \times H=15 \times 3.2=48 \mathrm{~m} \\
& L_{2}=48-18.75-2 \times 2.59-2 \times 6.4-5.6=5.67 \mathrm{~m} .
\end{aligned}
$$

c) Length of launching apron $(\mathrm{d} / \mathrm{s}), \quad L_{a}=2.5 d_{2}=2.5 \times 6.4=16 \mathrm{~m}$.

d) Length of launching apron (u/s), $L_{a}=2 d_{1}=2 \times 2.59=5.18 \mathrm{~m}$.

Recommended thickness of the launching apron in both $\mathrm{d} / \mathrm{s}$ and $\mathrm{u} / \mathrm{s}$ cases is (90 to100 cm) take $90 \mathrm{~cm}$.

e) $\mathrm{D} / \mathrm{s}$ concrete block $=1.5 d_{2}=1.5 \times 6.4=9.6 \mathrm{~m}$.

\section{Safety against Sub Surface Flow}

Hence, the cut off as shown in Figure 2 will be checked against two situations based on Bligh's theory;

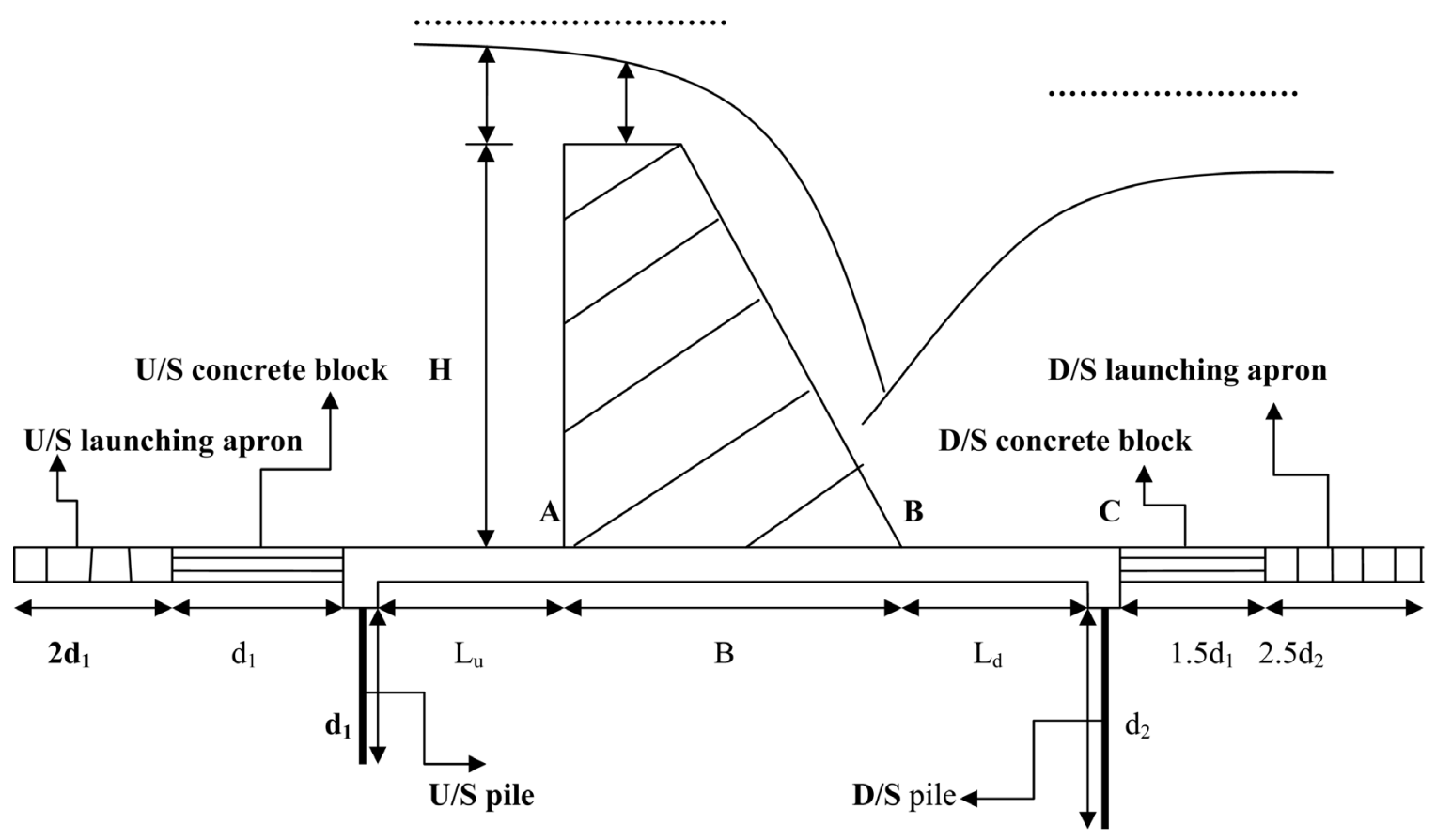




\section{a) Against Piping/Undermining}

$L=\frac{H}{L} \leq \frac{1}{C}$ For safety $C=15, H=3.2 \mathrm{~m}, L=$ Creep's length

$$
\begin{aligned}
& L=2 d_{1}+L_{2}+B+L_{1}+2 d_{2}=47.94 \mathrm{~m} \\
& L=\frac{3.2}{47.94} \leq \frac{1}{15}=0.06 \leq 0.067 \text { safe!! }
\end{aligned}
$$

\section{b) Against Uplift Pressure}

$$
L=0.06
$$

Therefore for each residual head at points as shown in Figure 2 parts A, B and C, the apron is provided with those thicknesses against the uplift.

\section{2) Design of Retaining Wall (Wing Wall)}

$$
H_{\max }=\text { river bed level }+ \text { weir height }+ \text { design head }=1858.5+3.2+2.83=1867.53 \mathrm{~m}
$$

\section{Design of U/S Wing Wall}

Height of the wing wall, $H_{w w}=H_{d}+H+$ free board $=2.83+3.2+0.75=6.78 \mathrm{~m}$

Crest level of the wing wall $=H_{w w}+$ river bed level $=6.78+1858.5=1865.28$

$$
\begin{gathered}
\text { Bottom width }=2 / 3 \times H_{w w}=2 / 3 \times 6.78=4.52 \mathrm{~m} \\
\text { Top width }=1 / 7 \times H_{w w}=1 / 7 \times 6.78=0.96 \mathrm{~m}
\end{gathered}
$$

\section{Design of D/S Wing Wall}

Tail water depth from stage discharge curve on the value of peak discharge $104.88 \mathrm{~m}^{3} / \mathrm{sec}$ is $3.24 \mathrm{~m}$. It is found in Appendix.

Height $H_{w w}=$ tail water depth + free board $=3.24+0.9=3.99$.

Crest elevation $=1858.5+3.99=1862.49 \mathrm{~m}$.

Bottom or base width, $B_{1}=2 / 3 \times H=2 / 3 \times 3.99 \mathrm{~m}=2.66 \mathrm{~m}$.

Top width, $B_{2}=\frac{H}{7}=\frac{3.99 \mathrm{~m}}{7}=0.57 \mathrm{~m}$.

\section{3) Design of under Sluice}

It should be capable of passing about $10 \%$ to $15 \%$ percent of the maximum flood.

$Q_{s}=0.1 Q_{d}$ to $0.15 Q_{d}, Q_{d}=104.88 \mathrm{~m}^{3} / \mathrm{sec}$.

For effective scouring action its dimension is made to be $1 \mathrm{~m} \times 1.5 \mathrm{~m}$

Discharge through the under sluice during high flood time

$$
\begin{gathered}
Q=C \times L \times H_{e}^{3 / 2}=1.7 \times 1 \times 2.97^{3 / 2}=13.05 \mathrm{~m}^{3} / \mathrm{s} \\
C=\text { Coefficient of discharge }=1.7
\end{gathered}
$$

From Bligh’s recommendations

$$
\begin{aligned}
q & =\frac{Q}{L}=10.488 \mathrm{~m}^{3} / \mathrm{sec}, \quad H=3.2 \mathrm{~m}, C=12 \\
L_{3} & =27 C \sqrt{\frac{H}{13} \times \frac{q}{75}}=27 \times 12 \times \sqrt{\frac{3.2}{13} \times \frac{10.488}{75}}=60.1 \mathrm{~m}
\end{aligned}
$$

The length of impervious apron upstream of the sluice gate

$$
L_{2}=3.87 \times C \times \sqrt{\frac{H}{13}}=3.87 \times 12 \times \sqrt{\frac{3.2}{13}}=23.04 \mathrm{~m}
$$

The recommended thickness for impervious apron at upstream and downstream side of the under sluice portion is $0.9 \mathrm{~m}$. 


\subsubsection{Canal Design}

\section{1) Lined Canal Design}

As shown in Figure 3 the reason why we need the portion to be lined is that, since our canal passes through hill zones the canal may be unstable.

The discharge (demand) is too small; the recommended shape of the lined canal is rectangular which requires lower cost than trapezoidal shape canal.

\section{Canal Cross-Section}

$Q=$ design discharge $=230 \mathrm{lit} / \mathrm{sec}=0.23 \mathrm{~m}^{3} / \mathrm{sec}, S=$ longitudinal slope $=1: 1000, n=$ The Roughness coefficient $=0.017$.

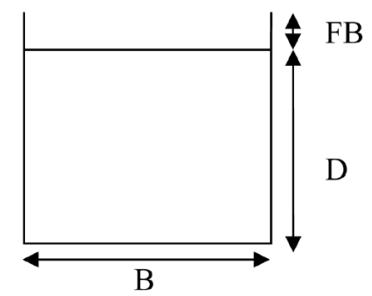

Cross sectional area $(A)=$ base $\times$ depth $=B \times D$.

Wetted perimeter $P=2 D+B$.

Hydraulic radius, $R=\frac{A}{p}=\frac{D B}{2 D+B}$, For having economic section canal $R=D / 2$.

Therefore, $\frac{D}{2}=\frac{D B}{2 D+B}, 2 D+B=2 B, 2 D=B, D=0.5 B$.

$$
A=D B=0.5 B^{2} \text { and } R=D / 2=0.5 B / 2=0.25 B
$$

\section{From manning's equation}

$$
Q=\frac{1}{n} \times A \times R^{\frac{2}{3}} \times s^{\frac{1}{2}}, \quad B=0.83 \mathrm{~m}, \quad D=\frac{B}{2}=0.41
$$

Adding freeboard $0.2 \mathrm{~m}$ the full supply depth of the canal will be, $D=0.61 \mathrm{~m}$.

The cross sectional dimension of the lined canal will be $B=0.83 \mathrm{~m}, D=0.61 \mathrm{~m}$,

$$
A=\frac{B^{2}}{2}=\frac{0.83^{2}}{2}=0.34 \mathrm{~m}^{2}, \quad P=2 D+B=2 \times 0.61+0.83=2.05 \mathrm{~m}, \quad R=A / p=0.16 \mathrm{~m}
$$

By using manning's formula for not silting and scouring the canal velocity should be between (0.3 and 0.6$)$ $\mathrm{m} / \mathrm{sec} . \quad V=\frac{1}{n} \times R^{\frac{2}{3}} \times S^{\frac{1}{2}}=0.56 \mathrm{~m} / \mathrm{s}$.

Therefore, the velocity is non-silting and non-scouring.

\section{2) Design of Unlined Canal}

Unlined canal are popular because of their low capital cost and ease of construction. As shown in Figure 4 they are best suited to relatively flat land with cohesive soil with low infiltration capacity. For the Jigessa small scale project Shape: trapezoidal is recommended for the sake of slope stability of the side walls of the canal.

$Q=$ design discharge $=0.230 \mathrm{~m}^{3} / \mathrm{sec}, S=$ longitudinal slope $=1: 1000, n=$ The Roughness coefficient $=0.025$, $S=$ side slope $1: 1$.

$$
\begin{gathered}
A=A_{1}+A_{2}+A_{3}=\frac{D^{2}}{2}+D \times B+\frac{D^{2}}{2}=D^{2}+(D \times B) \text { and } P=2 \sqrt{2} D+B \\
\therefore \quad R=\frac{A}{p}=\frac{D^{2}+D B}{2 \sqrt{2} D+B}
\end{gathered}
$$




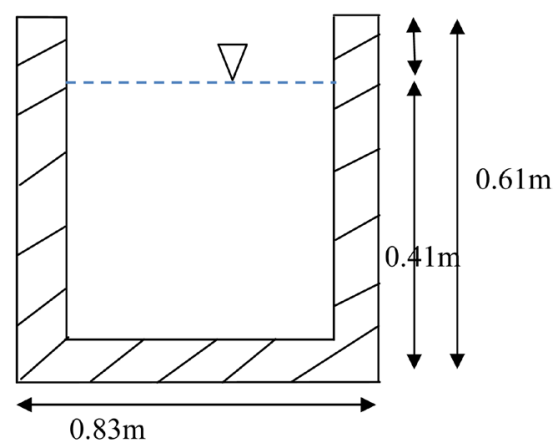

Figure 3. Cross-section of lined canal.

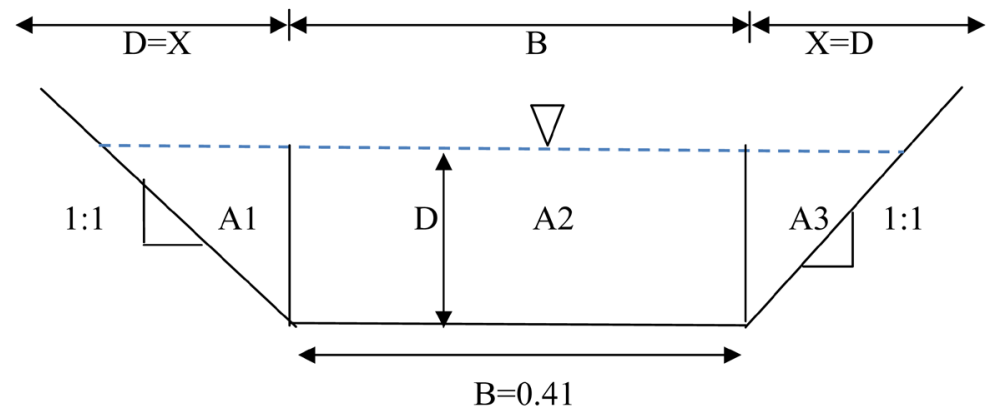

Figure 4. Cross-section of unlined canal.

For economic cross section, $R=D / 2$

$$
\begin{gathered}
R=\frac{A}{p}=\frac{D^{2}+D B}{2 \sqrt{2} D+B}=\frac{D}{2}, B=0.83 D, \quad D=\frac{B}{0.83}=1.205 B \\
P=2 \sqrt{2} \times 1.205 B+B=4.41 B \text { and } A=D^{2}+(D \times B)=2.657 B^{2} \\
R=\frac{A}{p}=0.602 B
\end{gathered}
$$

\section{By using manning's formula}

$$
Q=\frac{1}{n} \times A \times R^{\frac{2}{3}} \times s^{\frac{1}{2}}, \quad B=0.41 \mathrm{~m}, \quad D=0.5 \mathrm{~m}
$$

Adding freeboard $0.2 \mathrm{~m}$ the full supply depth of the canal will be, $D=0.7 \mathrm{~m}, A=0.44 \mathrm{~m}^{2}, P=1.80 \mathrm{~m}$ and $R=0.243 \mathrm{~m}$.

By using manning's formula for not silting and scouring the canal velocity should be between (0.3 and 0.6) $\mathrm{m} / \mathrm{sec}$. $V=\frac{1}{n} \times R^{\frac{2}{3}} \times s^{\frac{1}{2}}=0.58 \mathrm{~m} / \mathrm{sec}$.

\section{Conclusions}

The design analysis of Jigessa small scale irrigation project is generally carried out by integrating different disciplines like: irrigation agronomy, soil and water conservation engineering, surface water hydrology, survey, etc.

The structure we design in this project will resist the 50 year return period peak flood. As a result of this, the structure will be stable, safe and effective in terms of delivering adequate amount of water to the beneficiaries through a conveyance system (canal) without clogging by silting. So there will not be water scarcity and moisture stresses.

Therefore, this project has been proposed mainly to overcome food insecurity in the Woreda and to produce 
throughout the year using irrigation.

Generally, the project will be effective if and only if the command area and the water are managed and used appropriately.

\section{Recommendation}

In general, based on the problems we encounter and for sustainability of this project, we recommend the following:

$>$ As we know that most irrigation projects need data from meteorology station for effective and reliable design. But we could not get such type of data because in our project area there was no meteorology station and/or the nearby station could not give us available information. In order to reduce the problem, the government should spread wide metrology stations on local areas to give efficient and valuable data for the implementation of an irrigation scheme and other purposes. .

> Different conservation practice should also be applied after construction for the sustainability the structures.

$>$ Development without participation beneficiaries is like a house without foundation. The community should participate during the construction phase.

$>$ Even though farmers of the project area have an experience in crop production through irrigation, encouraging them to have adequate experience on operation, maintenance and managements of modern irrigation system is obligatory for the success of the project.

\section{Acknowledgements}

We would like to thank heartily and deeply our advisor Mr. Mihret. D. (Msc.) for his valuable advice, constructive comment and giving much of his time for us. Our deepest thanks also go to our coordinator Mr. Desalegn. J. (Msc.) for his encouragement. And special thanks for all our friends for their idea sharing and help.

\section{References}

[1] Garg, S.H. (1989) Irrigation Engineering and Hydraulic Structures. Khanna Publishers, Delhi.

[2] http://www.mowr.gov.et/

[3] Zemene (2009) Training on the Design of Hydraulic Structures (Design of Weir and Pump). Bahir Dar.

[4] Basak, N.N. (2003) Irrigation Engineering. IataMcGraw-Hill Publishing Company Limited, New Delhi.

[5] Arora, K.R. (1996) Irrigation Water Power and Water Resource Engineering. Standard Publication Distributors, Naisarak Delhi.

[6] Girma, M.M. and Awulachew, S.B. (2007) Irrigation Practices in Ethiopia: Characteristics of Selected Irrigation Schemes. International Water Management Institute, Colombo.

[7] Punmia, B.C. (1992) Irrigation and Water Power Engineering Naxmi Publications (p). New Delhi.

[8] Subramanya, K. (2008) Engineering Hydrology. Tata McGraw-Hill Publishing Company Limited, New Delhi. 


\section{Appendix}

Graph from the discharge curve, the design flood equivalent to the flood mark (3.24) was $104.88 \mathrm{~m}^{3} / \mathrm{sec}$. Here, the flood mark is equivalent to the Tail Water Depth (TWD).

\section{Stage-Discharge Curve}

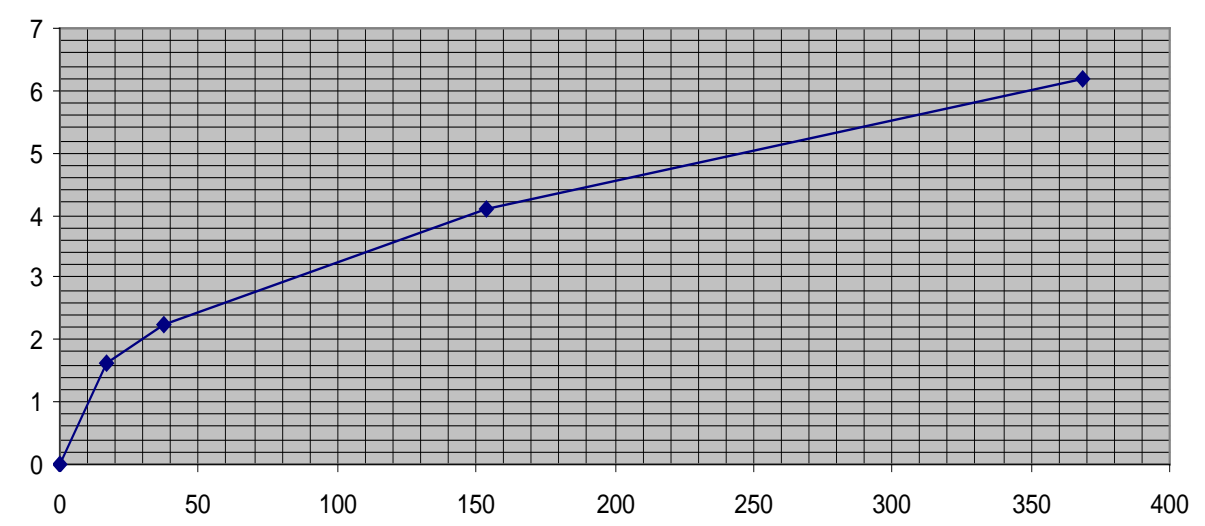

